\title{
Use of a therapeutic communication application in the Nursing undergraduate program: randomized clinical trial*
}

\author{
Manuela de Mendonça Figueirêdo Coelho ${ }^{1}$ \\ (1D) https://orcid.org/0000-0001-6182-9486 \\ Karla Corrêa Lima Miranda ${ }^{2}$ \\ (iD) https://orcid.org/0000-0001-6738-473X \\ Regina Claúdia de Oliveira Melo ${ }^{1}$ \\ (1) https://orcid.org/0000-0002-8323-8465 \\ Linicarla Fabiole de Souza Gomes ${ }^{3}$ \\ (iD) https://orcid.org/0000-0001-8582-6992 \\ Ana Ruth Macêdo Monteiro² \\ (iD) https://orcid.org/0000-0002-1130-1293 \\ Thereza Maria Magalhães Moreira² \\ (D) https://orcid.org/0000-0003-1424-0649
}

Objective: to analyze the effect on the knowledge of therapeutic communication by Nursing students through the use of applications. Method: a randomized and controlled clinical trial conducted with 60 nursing students. In the topic Groups and therapeutic communication techniques, the interventionIG group $(n=30)$ used the application and the control-CG group $(n=30)$ was submitted to the traditional class. The pre- (Zero Test -0) and post-test knowledge (immediate-Test 1 and after 30 day-Test 2) of those involved were evaluated. Results: Test 1, performed immediately after the intervention, showed a mean of 11 hits in the control group and 13 in the intervention, with statistical significance $(p=0.036)$. Test 2 showed a decrease in hits in both groups ( $\mathrm{IG}=10.87$ and $C G=9.3$ ), but maintained the difference between IG and CG in the post-test $(p<0.01)$. Conclusion: the use of the application on therapeutic communication favored the knowledge of the students, when compared to the traditional teaching method. REBEC RBR-4TF6MR Registration.

Descriptors: Educational Technology; Randomized Controlled Trial; Higher Education; Nursing; Mobile Applications; Communication.

\section{How to cite this article}

Coelho MMF, Miranda KCL, Melo RCO, Gomes LFS, Monteiro ARM, Moreira TMM. Use of a therapeutic communication application in the Nursing undergraduate program: randomized clinical trial. Rev. Latino-Am. Enfermagem. 2021;29:e3456. [Access $\underset{\text { month }}{\frac{1}{1}} \frac{1}{1} \underset{\text { year }}{i}$; Available in: DOI: http://dx.doi.org/10.1590/1518-8345.4461.3456. 


\section{Introduction}

The Nursing undergraduate courses aim to accompany changes in the health needs of society, the training process and health work. Integrated disciplines, active and student-centered methods have been a relevant challenge, instigating students and teachers to overcome the traditional method of teaching-learning ${ }^{(1-2)}$. A study predicts that soon nurses will experience their practice permeated with technology, requiring curricular adaptation ${ }^{(3-6)}$ that favors the early use of media resources in the undergraduate course and in care, as in the case of mobile devices or applications (APPs) $^{(7-9)}$.

Although there is no guideline or legislation on the use of applications for teaching, the Brazilian Ministry of Education created the International Bank of Educational Objects, which provides virtual tools produced by teachers in free format, with multiple platform and language. But this bank has received few registrations, raising the need to increase its production ${ }^{(10)}$.

In this sense, review studies(11-12) denote the adoption of multiple Learning Objects (OAs), such as blogs, chats, wikis and virtual simulations, in the increase of knowledge and autonomy of students, especially in the health area, suggesting their testing in clinical trials for the production of scientific evidence ${ }^{(12)}$.

When considering the complexity of nursing care, which requires the nurse, polysemy and completeness of content ${ }^{(13)}$, communication is the basic instrument of care, allowing centralization in the user and in their singularities ${ }^{(14)}$. Communication, whether verbal, nonverbal or para-verbal, is strongly present in the practice of the nurse, constituting action, including therapeutic, as the actions of nursing care provided to pregnant women, deaf people, mother-child binomial, critical patients, among others ${ }^{(15-18)}$.

The theoretical reference of communication adopted in this study was that of Maguida Costa Stefanelli, who considers the communication in Nursing as an integrator between assistance, teaching and research, being fundamental in the care, educational practice and health care(19-20). Thus, the objective of this study was to analyze the effect on the knowledge of therapeutic communication by Nursing academics using applications

\section{Method}

A parallel randomized clinical trial conducted from February to March 2017 with undergraduate Nursing students from a private faculty in the Fortaleza-Ceará educational network. Participants were randomly separated into two groups: Intervention Group (IG) (class using APP on therapeutic communication) and Control Group (CG) (traditional expository class on the same theme).

The intervention took place on a school day of the discipline "Psychological Basis for the Care Process", in the class on "therapeutic communication". In the curricular matrix of the course, this subject is taught in the third semester. The population of the study was 146 students enrolled in the discipline and the sample was 121 of these who were present in class during the data collection. The subject was taught in different shifts, minimizing the contact between participants.

Grouped randomization via www.random.org was used and the classes of the three shifts had the same chance to participate in the IG and the $\mathrm{CG}^{(21)}$, because the computerized algorithm defined which group would receive the intervention and which would be the control. Grouped randomization was chosen because individual randomization would not guarantee that students from the same class and different groups in the research would exchange information about the study.

In the institution researched, the Nursing course has existed for 15 years, currently with a maximum grade of five by the Ministry of Education (MEC), having already graduated more than two thousand nurses. It was found the absence of any discipline with systematic use of APP in teaching. It was inclusion criterion: to have smartphone with Android operating system compatible with the execution of APP (the tool was produced in Java programming language and, initially, only for such operating system). The exclusion criteria were defined as: previous failure in the subject; being under 18 years old and claiming not to have basic computer knowledge or use of technology. It was discontinuity criteria: no follow-up in post-test 1 (students who left the classroom before the end of the class) and/or post-test 2 (30 days after the intervention, two visits were made to the classroom, with 30-minute intervals between one visit and another, not finding the student).

To ensure blinding, the principal researcher (creator of APP) did not attend the class at IG and CG. The class, in both groups, was taught by an external researcher teacher, experienced, trained and experienced in teaching the subject, directed by a Standard Operating Procedure (POP). The POP detailed how the IG and CG class should be, containing the educational objective and the detailed description of the approach and the activities to be carried out by the teacher.

The difference between the IG and the CG was in the discussion about groupings and therapeutic communication strategies, carried out in the CG in an expository-dialogue way and mediated by PowerPoint slides, and in the IG with the handling and exploration 
of the APP. The same researcher, who taught the class at IG and CG, applied the data collection questionnaire in all three stages. Blinding in educational interventions is complex and needs to minimize possible co-interventions and blind, minimally, the responsible for the evaluation and adjudication of the outcomes, diminishing biases of the principal researcher in a differentiated look to the $\mathrm{IG}^{(21)}$.

The IG and CG classes began with the conceptual presentation of human communication, its forms and functions, therapeutic relationship, groupings (expression, clarification and validation) ${ }^{(19)}$ and strategies of therapeutic communication (silence, listen reflexively, verbalize acceptance, verbalize interest, use open sentences, repeat user comments, ask questions, return the question asked, use descriptive phrases, allow the user to choose the subject, focus on the main idea, verbalize doubts, say no, stimulate the expression of feelings, use humor therapeutically, stimulate comparisons, request clarification of unusual terms, identify the agent of the action, describe events in logical sequence, repeat the user's message, request the user to repeat what was said, summarize the content of the interaction) ${ }^{(19)}$.

The CG class was taught in the morning group and held exposition with the PowerPoint feature and duration of one hour and 47 minutes. In the night group (IG), following the POP, in the topic Groups and therapeutic communication strategies, the APP "Therapeutic Communication" was used. For this, students were guided to download the APP in temporary link using a specific login and password. The APP resources were handled, which also contained an interactive video about the practice of content. This class lasted one hour and 52 minutes. They were told to feel free to explore the APP, watch and interact with the video and that they could dialogue through the teacher's exposure and the content of the APP. After the class, students' access to APP was cancelled to prevent other students from accessing it. It should be noted that APP was produced and validated for this essay, and this methodological study is under evaluation in a journal for later publication.

The APP presents each therapeutic communication strategy, as well as its referred grouping, with clinical examples and a video with a simulation of the Nursing consultation in which the student can identify the various strategies used, thus being able, in addition to obtaining a theoretical contextualization, to identify, in simulation, the use of the techniques during clinical practice.

Before the IG and CG class (Moment 0/MO), the Learning Verification Test (TVA) was applied to the students, which was reapplied immediately after the end of the class (Moment 1/M1) and 30 days after (Moment 2/M2). The follow-up, after 30 days of class, was given to compare immediate and long-term learning.

The TVA was built by researchers based on a literature review on the subject and validated by seven expert judges. With a maximum score of up to twenty points, it contains questions of sociodemographic characterization [age (self-declared in years), gender, marital status and occupation] and 20 open questions worth one point each on the concept of communication, practices with grouping and situations to identify the use of therapeutic communication techniques.

The outcome was the learning (acquired knowledge) defined as the ability of the participants to identify groups of therapeutic communication, associate their respective strategies and use them in specific clinical situations in M0, M1 and M2. The average time to fill the TVA was nine minutes.

The data was processed in the Statistical Package for the Social Sciences (SPSS), version 22.0, and presented in graphs and tables. After verifying data normality with the Kolmogorov-Smirnov test for independent samples, Student's test was used to compare means and Fisher's exact test. Analysis of variance (one-way ANOVA) was used for intergroups with Sidak post-hoc analysis. The 95\% confidence interval and statistical significance were considered when $p<0.05$. The study was approved by the Ethics Committee of the State University of Ceará (UECE), with the Ordinance No. 1.570.217, and registered in the Clinical Trials Registry platform (REBEC) with the number RBR-4TF6MR.

\section{Results}

Of the 121 students invited, 104 met the inclusion criteria and accepted to participate in the study, 50 were assigned to IG and 54 to CG. During the research, the IG had 11 losses for absence in the M1 and another nine for absence in the M2, ending with 30 students. In the CG, there were ten losses for absence at the M1 and 14 more for absence at $M 2$, ending also with 30 participants (Figure 1). The recruitment and follow-up took place in February and March of 2017. 


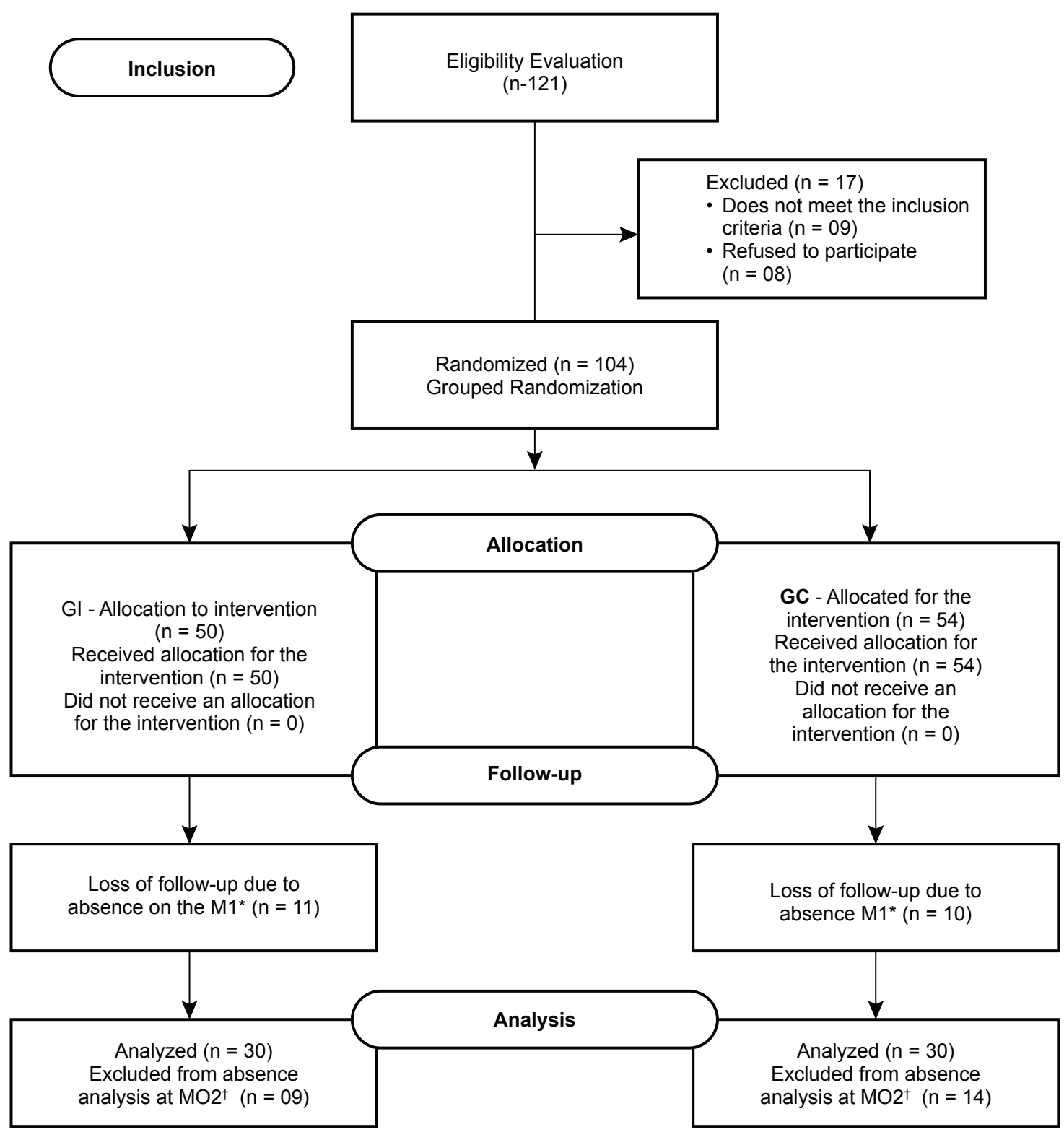

*Moment 01; ${ }^{+}$Moment 02

Figure 1 - CONSORT diagram. Fortaleza, Ceará, Brazil, 2017

The mean age was 24.4 years $(S D=3.8)$ in IG and $21.3(S D=4.2)$ in $C G$, where age homogeneity was confirmed $(p=0.301)$. Occupation $(p=0.873)$, marital status $(p=0.651)$ and gender $(p=0.582)$ were also homogeneous between groups (Table 1 ).

The average of inter-group hits was similar at MO, being 7.37 at IG and 7.27 at CG, without statistical significance, announcing the homogeneity in the previous knowledge of the content between the two groups (Table 2).
Table 1 - Characterization of the participants of the Intervention Group (IG) and Control Group (CG). Fortaleza, Ceará, Brazil, 2017

\begin{tabular}{lccccc}
\hline Variables & $\begin{array}{c}\text { Intervention Group } \\
\text { IG }\end{array}$ & \multicolumn{2}{c}{$\begin{array}{c}\text { Control Group } \\
\text { CG }\end{array}$} & $\mathbf{p}^{*}$ \\
\hline Work & $\mathbf{N}$ & $\%$ & $\mathbf{n}$ & $\%$ & \\
Yes & 12 & 60.0 & 08 & 40.0 & .873 \\
No & 18 & 35.0 & 22 & 55.0 & \\
\hline Marital & & & & & .651 \\
Status & & & & & \\
Married & 10 & 60.0 & 08 & 40.0 & \\
$\quad$ Not Married & 20 & 35.0 & 22 & 55.0 & \\
\hline Sex & & & & & \\
$\quad$ Female & 28 & 54.9 & 23 & 45.0 & $\mathbf{5 8 2}$ \\
$\quad$ Male & 02 & 22.3 & 07 & 77.7 & \\
\hline
\end{tabular}

${ }^{*}$ Fisher's exact test 
Table 2 - Mean of hits, standard deviation and p-value of the mean of IG and CG at Moments M0, M1 and M2. Fortaleza, Ceará, Brazil, 2017

\begin{tabular}{cccccccccc}
\hline & \multicolumn{3}{c}{ Pre-test } & \multicolumn{3}{c}{ Post-test 1 (Immediate) } & \multicolumn{3}{c}{ Post-test 2 (30 days) } \\
\cline { 2 - 10 } & Average of hits & $\mathbf{S D}^{*}$ & $\mathbf{p}^{\dagger}$ & Average of hits & $\mathbf{S D}^{*}$ & $\mathbf{p}^{\dagger}$ & Average of hits & SD $^{*}$ & $\mathbf{p}^{\dagger}$ \\
\hline IG & 7.37 & 2.84 & & 13 & 2.80 & & 10.87 & 2.5 & \\
CG & 7.27 & 2.27 & .945 & 11 & 2.10 & .036 & 9.3 & 2.7 & $\mathbf{0 . 0 1}$ \\
\hline
\end{tabular}

*Standard Deviation; ${ }^{\dagger}$ Valor of $\mathrm{p}$ obtained from Student's t test

In the $M 1$, the IG had an average of 13 hits and the CG had 11 hits, with statistical significance between groups $(p=0.036)$. In $M 2$, the number of hits of both groups decreased (IG $=-2.13+2.5$ and $C G=-1.7+2.7$ ), but the difference between IG and CG remained, with statistical significance $(p=0.01)$. Moreover, in IG, the decrease of the mean hits was numerically smaller than the standard deviation and larger than the CG, although the standard deviation decreased in IG and increased in CG, when comparing [M1 - (minus) M2] to [M1 - (minus) M0], showing greater homogeneity in the hits of students in IG.

Even with more students decreasing their grades in M2, still the students in IG showed higher values than those in CG, with statistical significance $(p=0.028)$ and greater homogeneity of values (Table 3 ). The study was finalized after data collection from M2.

Table 3 - Number of hits and difference per IG and CG participant at M0, M1 and M2. Fortaleza, Ceará, Brazil, 2017

\begin{tabular}{|c|c|c|c|c|c|c|c|c|c|c|}
\hline \multirow[t]{2}{*}{ Student (S) } & \multicolumn{5}{|c|}{$\begin{array}{c}\text { Number of hits and difference between the } \\
\text { moments (M0-M1-M2) of the Intervention } \\
\text { Group (IG) }\end{array}$} & \multicolumn{5}{|c|}{$\begin{array}{l}\text { Number of hits and difference between the moments (M0- } \\
\text { M1-M2) of the Control Group (CG) }\end{array}$} \\
\hline & Mo & M1 & M1-M0 & M2 & M2-M0 & MO & M1 & M1-M0 & M2 & M2-M0 \\
\hline S01 & 11 & 15 & +04 & 13 & +02 & 08 & 14 & +04 & 10 & +02 \\
\hline S02 & 03 & 12 & +09 & 10 & +07 & 06 & 10 & +04 & 07 & +01 \\
\hline S03 & 05 & 09 & +04 & 10 & +05 & 02 & 10 & +08 & 11 & +09 \\
\hline S04 & 09 & 11 & +02 & 11 & +02 & 07 & 09 & +02 & 08 & +01 \\
\hline S05 & 12 & 17 & +05 & 15 & +03 & 06 & 12 & +06 & 12 & +06 \\
\hline S06 & 07 & 14 & +07 & 13 & +06 & 07 & 08 & +01 & 08 & +01 \\
\hline S07 & 06 & 13 & +07 & 12 & +06 & 11 & 11 & 00 & 13 & +02 \\
\hline S08 & 09 & 17 & +08 & 15 & +06 & 05 & 15 & +10 & 07 & +02 \\
\hline S09 & 04 & 08 & +04 & 07 & +03 & 06 & 12 & +06 & 04 & +02 \\
\hline S10 & 09 & 15 & +06 & 14 & +05 & 10 & 11 & +01 & 10 & 00 \\
\hline $\mathrm{S} 11$ & 07 & 15 & +08 & 11 & +04 & 11 & 11 & 00 & 11 & 00 \\
\hline $\mathrm{S} 12$ & 10 & 12 & +02 & 09 & -01 & 12 & 15 & +03 & 15 & +03 \\
\hline $\mathrm{S} 13$ & 08 & 15 & +07 & 13 & +05 & 07 & 10 & +03 & 09 & +02 \\
\hline S14 & 04 & 09 & +05 & 08 & +04 & 07 & 11 & +04 & 09 & +02 \\
\hline S15 & 13 & 17 & +04 & 14 & +01 & 06 & 10 & +04 & 09 & +03 \\
\hline S16 & 06 & 12 & +06 & 10 & +04 & 09 & 10 & +01 & 08 & -01 \\
\hline S17 & 14 & 17 & +03 & 15 & +01 & 06 & 10 & +04 & 05 & -01 \\
\hline S18 & 04 & 10 & +06 & 07 & +03 & 06 & 12 & +06 & 09 & +03 \\
\hline S19 & 10 & 16 & +06 & 12 & +02 & 09 & 13 & +04 & 11 & +02 \\
\hline $\mathrm{S} 20$ & 05 & 11 & +06 & 09 & +04 & 12 & 12 & 00 & 14 & +02 \\
\hline S21 & 09 & 17 & +08 & 14 & +05 & 06 & 15 & +09 & 14 & +08 \\
\hline S22 & 08 & 17 & +09 & 12 & +04 & 07 & 12 & +05 & 10 & +03 \\
\hline S23 & 05 & 12 & +07 & 07 & +02 & 08 & 09 & +01 & 05 & +03 \\
\hline S24 & 06 & 11 & +05 & 09 & +03 & 05 & 09 & +04 & 06 & +01 \\
\hline S25 & 08 & 14 & +06 & 11 & +03 & 07 & 08 & +01 & 11 & +04 \\
\hline S26 & 04 & 15 & +11 & 10 & +06 & 06 & 13 & +07 & 07 & +01 \\
\hline S27 & 07 & 10 & +03 & 09 & +02 & 09 & 10 & +01 & 09 & 00 \\
\hline S28 & 05 & 12 & +07 & 07 & +02 & 05 & 07 & +02 & 07 & +02 \\
\hline S29 & 05 & 10 & +05 & 09 & +04 & 06 & 12 & +06 & 10 & +04 \\
\hline S30 & 08 & 12 & +04 & 10 & +02 & 06 & 09 & +03 & 11 & +05 \\
\hline
\end{tabular}


Both IG and CG showed more hits on M1 and M2 than on M0. In IG, the difference in the learning average [M1 (immediate)-M2 (30 days)] had an effect on learning within 30 days, although in many cases lower at M2 than at M1. In the case of CG, some students decreased or returned to the value obtained in MO.
The ANOVA test showed the effect of the intervention on learning by students from IG $(p<0.001)$ and CG ( $p<$ 0.001 ). Sidak's post-hoc showed a significant difference between all moments in both groups (intragroup).

The following Figure 2 compares the averages of hits of the two groups at the three moments, associated with the trend lines.

20

15

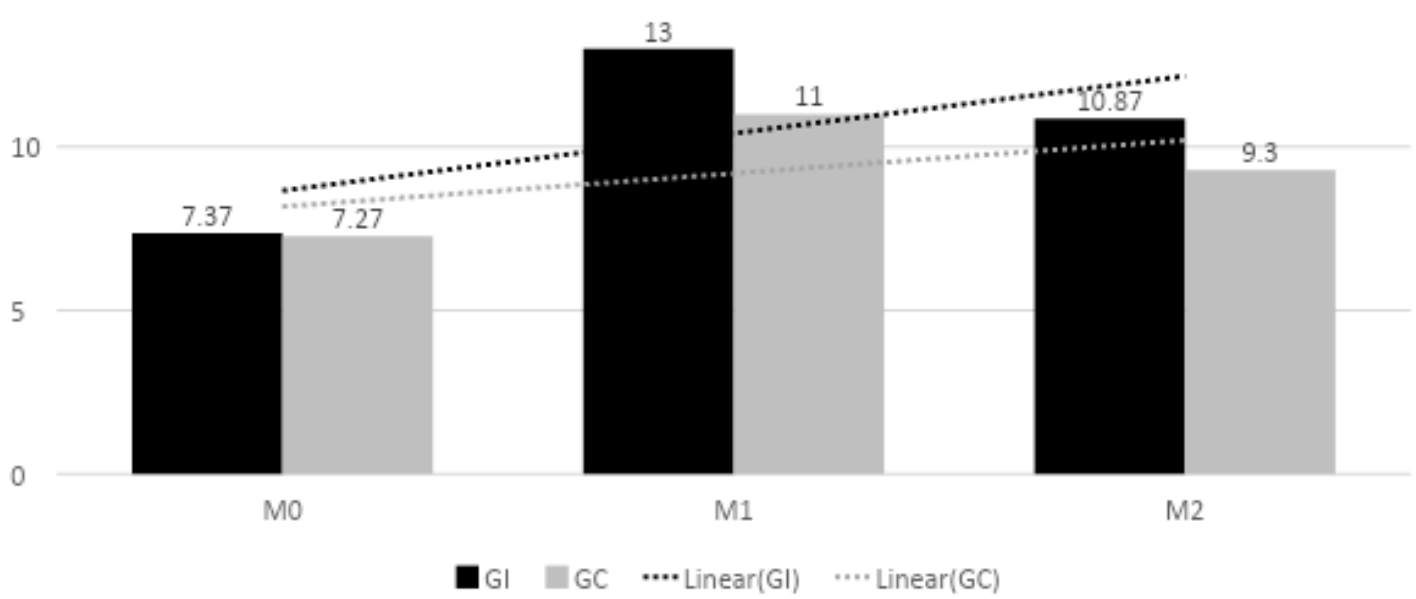

Figure 2 - IG and CG average hits at Moments M0, M1 and M2 with their trend lines. Fortaleza, Ceará, Brazil, 2017

\section{Discussion}

At first, it should be considered that in experimental research, sampling bias is a significant problem. Thus, getting homogeneous samples, even unrepresentative ones, is one of the ways to minimize this issue ${ }^{(21)}$. The similarity in the study groups with the two groups is a way to ensure that they have the same characteristics, configuring the intervention as the only different variable to permeate the study ${ }^{(22)}$.

The on-screen study reveals that the average grades of the two moments after the intervention (M1 and M2) were higher in IG. A research carried out in Fortaleza presented an increased average of hits after educational intervention with APP, denoting the positive influence of this technology in the knowledge of students( ${ }^{(23)}$. Similarly, in this study, the APP on the therapeutic communication in commentary had an effect on the learning of students in Nursing, which can have repercussions on the therapeutic communication of Nursing(24). At Washington State University, research on the use of APP in teaching-learning was conducted and it was proven that the use of APP by students contributes to learning $(p=0.01)^{(25)}$.
Therapeutic communication needs to be further explored by nurses in teaching and interactions during care. Communication strategies are powerful tools, but underused in the professional exercise of Nursing(26), prompting reflections on communicational instrumentation during professional training. But it is worth mentioning that there may be confusion between the therapeutic communication strategies and the subjective issues of the professional, making affection, solidarity and compassion, among other feelings, be referred to as communication strategies. However, therapeutic communication techniques have specific groupings and are endowed with goals and indications for their use ${ }^{(27)}$, which should facilitate its application in the clinical practice of Nursing.

Therapeutic communication can be developed, that is, it is not necessarily a "born" constituent of the professional. Thus, since communication permeates the nurse-patient therapeutic relationship, it also requires study, nurse's skill and applicability in the daily life of this area. This need can be met, in part, with the study via APP, which has already been verified, even in intervention in a shorter time (15 days) $)^{(28)}$. 
A Peruvian clinical trial measured the knowledge acquired by nursing students after using APP to teach tracheostomy tube aspiration and pointed out that the knowledge of students who used APP was superior and of statistical significance $(p=0.003)$ to the traditional one, recommending the adoption of such a device(29).

A meta-analysis of 11 clinical trials showed the increase in learning via APP for nurses and students, stating that there is good support and positive influence on Nursing education( ${ }^{(30)}$. However, using smartphones during the lesson can also be a distraction ${ }^{(31)}$, which can make it difficult to reach the intended goal.

The limitations of this study are the followup of patients for only 30 days and the use of the APP only once, in a single day, due to the need to finish the research. But the literature reinforces the need for therapeutic communication in professional exercise(24,26-27), although there is no description of how to do it. Thus, it has been proven that the application on therapeutic communication is conducive to teaching, being useful in situations of social withdrawal such as the one faced today.

\section{Conclusion}

The use of APP for group teaching and therapeutic communication strategies has shown an effect on the knowledge of students who have used the technology, as opposed to the traditional model. The knowledge remained greater in the intervention group, even after thirty days of use of APP, configuring itself into a powerful teaching tool.

This study presents important contributions to teaching in Nursing, demonstrating that APP can facilitate contemporary teaching and learning, thus calling on professionals to develop, validate and use tools for teaching. It is recommended, in the future, to verify the repercussions of the use of APP in clinical practice on other health matters and with larger samples and followup deadlines.

\section{References}

1. Baldoino AS, Veras RM. Analysis of Servicelearning activities adopted in health courses of Federal University of Bahia. Rev Esc Enferm USP. 2016 Jun;50(spe):17-24. doi: http://dx.doi.org/10.1590/ S0080-623420160000300003

2. Lana LD, Birner AJ. Case report on the construction and preparation of a portfolio as a learning assesment method. Cienc Enferm. 2015;21(3):101-12. doi: http:// dx.doi.org/10.4067/S0717-95532015000300009
3. Risling T. Educating the nurses of 2025: Technology trends of the next decade. Nurse Educ Pract. 2017;22:8992. doi: http://10.1016/j.nepr.2016.12.007

4. Oliveira LL, Mendes IC, Balsells MMD, Bernardo EBR, Castro RCMB, Barbos APS, et al. Educational hypermedia in nursing assistance at birth: building and validation of content and appearance. Rev Bras Enferm. 2019 Nov/ Dec;72(6):1471-8. doi: https://doi.org/10.1590/00347167/2018-0163

5. Mota NP, Vieira CMA, Nascimento MNR, Bezerras AM, Quirino GS, Félix NDC. Mobile application for the teaching of the International Classification for Nursing Practice. Rev Bras Enferm. 2019 July/Aug;72(4):1020-7. doi: https://doi.org/10.1590/0034-7167-2018-0751

6. Serafim ARRM, Silva ANS, Alcântara CM, Queiroz MVO. Construction of serious games for adolescents with type 1 diabetes mellitus. Acta Paul Enferm. 2019 Jan;32(4):374-81. doi: https://doi.org/10.1590/19820194201900052

7. Mackay BJ, Anderson J, Harding T. Mobile technology in clinical teaching. Nurse Educ Pract. 2017 Jan;22:1-6. doi: 10.1016/j.nepr.2016.11.001

8. Alvarez AG, Sasso GTMD, Iyengar MS. Persuasive technology in the teaching acute pain assessment in nursing: results in learning based on pre and posttesting. Nurse Educ Pract. 2017 Dec; 50:109-14. doi: 10.1016/j.nedt.2016.12.019

9. Salum NB, Junkes C, Amante LN, Mendez CML. Mobile educational follow-up application for patients with peripheral arterial disease. Rev. Latino-Am. Enfermagem. 2019 Jan 27(e3122):1-11. doi: https:// doi.org/10.1590/1518-8345.2693-3122

10. Bardy LR, Hayashi MCPI, Schlunzen ETM, Seabra Junior MO. Objects for Learning as educational resources in inclusive contexts: support for distance teacher education. Rev Bras Educ Esp. 2013 Abr/ Jun;19(2):271-88. doi: https://doi.org/10.1590/S141365382013000200010

11. Trindade CS, Dahmer A, Reppold CT. Learning Objects: An Integrative Review in Healthcare. J. Health Inform. [Internet]. 2014 [cited Apr 27, 2020];6(1):209. Available from: http://www.jhi-sbis.saude.ws/ojs-jhi/ index.php/jhi-sbis/article/view/300/187

12. Coelho MMF, Miranda KCL. Learning objects used in nursing students training: integration review. Rev Tend Enferm Profis. [Internet]. 2016 [cited Apr 27, 2020];8(4):2037-44. Available from: http://www. coren-ce.org.br/wp-content/uploads/2019/03/OBJETOSDE-APRENDIZAGEM-UTILIZADOS-NO-ENSINO-DEACADEMICOS-DE-ENFERMAGEM.pdf

13. Fernandes JD, Rebouças LC. A decade of National Curriculum Guidelines for Graduation in Nursing: advances and challenges. Rev Bras Enferm. 
2013;66(esp):95-101. doi: https://doi.org/10.1590/ S0034-71672013000700013

14. Amorim CB, Barlem ELD, Mattos LM, Costa CFS, Oliveira SG. Disclosure of difficult news in primary health care: aspects that hinder or facilitate communication from the perceptions of nurses. Rev Gaucha Enferm. 2019 Sep;40(e20190017):1-7. doi: https://doi. org/10.1590/1983-1447.2019.20190017

15. Beserra GL, Oliveira PMP, Pagliuca LMF, Almeida PC, Anjos SJSB, Pinheiro AKB. Non-verbal nurse-parturient communication in labor in Portuguese-speaking countries. Rev. Latino-Am. Enfermagem. [Internet]. 2019 [cited Apr 13, 2020];27(e3193):1-9. Available from: http://www.scielo.br/pdf/rlae/v27/0104-1169rlae-27-e3193.pdf. doi: https://doi.org/10.1590/15188345.3032 .3193

16. Sanches ICB, Bispo LP, Santos CHS, França LS, Vieira SNS. The role of the nurse in relation to the deaf patient. Rev Enferm UFPE On Line. 2019:13(3)85862. doi: https://doi.org/10.5205/1981-8963v13i03a238964p858-862-2019

17. Teixeira TRF, Avila MAG, Braga EM. Patients' understanding of nursing instructions in cardiac catheterism: a qualitative study . Cogitare Enferm. 2019 Ago:24(e56604):1-9. doi: http://dx.doi.org/10.5380/ ce.v24i0.56604

18. Costa AR, Nobre CMG, Gomes GC, Rosa GSM, Nornberg PKO, Medeiros SP. Perception of the family in a pediatric unit about nursing care. Rev Enferm UFPE On Line. 2018 Dez;12(12):327986. doi: https://doi.org/10.5205/1981-8963v12i12a238298p3279-3286-2018

19. Stefanelli MC. Estratégias de comunicação terapêutica. In: Stefanelli MC, Carvalho EC. A comunicação nos diferentes contextos da enfermagem. Barueri: Manole; 2005. p. 73-104.

20. Stefanelli MC. Teaching communication therapeutic techniques in nurse-patient relationship: conceptual basis - Part II. Rev Esc Enferm. 1987;21(2):107-15. doi: http://dx.doi.org/10.1590/0080-6234198702100200107 21. Hulley SB, Cummings SR, Brownwe WS, Grady DG, Neman TB. Delineando a pesquisa clínica. 4. ed. Porto Alegre: Artmed; 2015.

22. Kara-Júnior $\mathbf{N}$. Definition of population and randomization of sample in clinic surveys. Rev Bras Oftalmol. 2014;73(2):67-8. doi: 10.5935/0034.7280.20140015

23. Pereira FGF, Caetano JÁ, Frota NM, Silma MG. Use of digital applications in the medicament calculation education for nursing. Invest Educ Enferm. 2016 Jun;34(2):297-304. doi: 10.17533/udea.iee.v34n2a09 24. Dermani DB, Garbuio DC, Carvalho EC. Knowledge, applicability and importance attributed by nursing undergraduates to communicative strategies. Rev Bras Enferm. 2020;73(6):1-11. doi: http://dx.doi. org/10.1590/0034-7167-2019-0411

25. Keegan RD, Oliver MC, Stanfill TJ, Stevens KV, Brown $\mathrm{GR}$, Ebinger $M$, et al. Use of a Mobile Device Simulation as a Preclass Active Learning Exercise. J Nurs Educ. 2016 Jan;55(1):56-9. doi: 10.3928/01484834-20151214-14 26. Torres, GMC, Figueiredo IDT, Cândido JAB, Pinto AGA, Morais APP, Araújo MFM, et al. Therapeutic communication in the interaction between health workers and hypertensive patients in the family health strategy. Rev Gaúcha Enferm. 2017;38(4):1-8. doi: http://dx.doi. org/10.1590/1983- 1447.2017.04.2016-0066

27. Almeida KLS, Garcia DM. Use of communication strategies in palliative care in Brazil: integrative review. Cogitare Enferm. 2015;20(4):725-32. doi: http://dx.doi. org/10.5380/ce.v20i4.39509

28. Chuang YH, Lai FC, Chang CC, Wan HT. Effects of a skill demonstration video delivered by smartphone on facilitating nursing students' skill competencies and selfconfidence: A randomized controlled trial study. Nurse Educ Today . 2018 Jul;66:63-8. doi: 10.1016/j. nedt.2018.03.027

29. Bayram SB, Caliskan N. Effect of a game-based virtual reality phone application on tracheostomy care education for nursing students: A randomized controlled trial. Nurse Educ Today. 2019 Aug;79:25-31. doi: 10.1016/j.nedt.2019.05.010

30. Kim JH, Park H. Effects of Smartphone-Based Mobile Learning in Nursing Education: A Systematic Review and Meta-analysis. Asian Nurs Res (Korean Soc Nurs Sci). 2019 Feb;13(1):20-9. doi: 10.1016/j.anr.2019.01.005 31. Zarandona J, Cariñanos-Ayala S, CristóbalDomíngues E, Martín-Bezos J, Yoldi-Mitxelena, Cillero IH. With a smartphone in one's pocket: A descriptive cross-sectional study on smartphone use, distraction and restriction policies in nursing students. Nurse Educ Today . 2019 Nov; 82:67-73. doi: https://doi. org/10.1016/j.nedt.2019.08.001

\section{Authors' Contribution:}

Study concept and design: Manuela de Mendonça Figueirêdo Coelho, Karla Corrêa Lima Miranda. Obtaining data: Manuela de Mendonça Figueirêdo Coelho. Data analysis and interpretation: Manuela de Mendonça Figueirêdo Coelho, Karla Corrêa Lima Miranda. Statistical analysis: Manuela de Mendonça Figueirêdo Coelho. Drafting the manuscript: Manuela de Mendonça Figueirêdo Coelho, Karla Corrêa Lima Miranda, Regina Claúdia de Oliveira Melo, Linicarla Fabiole de Souza Gomes, Ana Ruth Macêdo Monteiro, Thereza Maria 
Magalhães Moreira. Critical review of the manuscript as to its relevant intellectual content: Manuela de Mendonça Figueirêdo Coelho, Karla Corrêa Lima Miranda, Regina Claúdia de Oliveira Melo, Linicarla Fabiole de Souza Gomes, Ana Ruth Macêdo Monteiro, Thereza Maria Magalhães Moreira.

All authors approved the final version of the text.

Conflict of interest: the authors have declared that there is no conflict of interest.

Received: May $12^{\text {th }} 2020$ Creative Commons (CC BY).

This license lets others distribute, remix, tweak, and build upon your work, even commercially, as long as they credit you for the original creation. This is the most accommodating of licenses offered. Recommended for maximum dissemination and use of licensed materials. 